\title{
Refashioning the EU Visa Policy: A New Turn of the Screw to Cooperation on Readmission and to Discrimination?
}

\author{
Salvatore Fabio Nicolosi \\ Assistant Professor, Department of International and European Law, \\ Faculty of Law, Economics and Governance, and Utrecht Centre for \\ Regulation and Enforcement in Europe (RENFORCE), Utrecht University, \\ Utrecht, The Netherlands \\ S.Nicolosi@uu.nl
}

\begin{abstract}
Since the establishment of the Schengen area, border management has been having momentum within the European Union (EU) and, one of its major building blocks is the common policy on visas. This allows to control who can have access to the Schengen area for short stays that do not exceed three months over any six-month period.

This article investigates how the EU visa policy has been influenced by the everevolving migratory dynamics towards the EU. Focusing on the latest reform of the Common Code on Visa, which has entered into force in 2020, this article argues that the new approach to conditionality in EU migration law has consolidated the intertwining between the EU visa policy and cooperation on readmission. Over the years, the latter has constituted an incentive for the EU in order to offer visa facilitation regimes or specific visa waivers to nationals of third countries. However, this article criticizes the new mechanism, introduced by the recent reform, and providing the European Commission with the mandate to propose specific restrictive measures related to visa processing and visa fee in case of a lack of cooperation especially on readmission. In an attempt to shed light on the legal concerns raised by this mechanism, the paper concludes that it even emphasises the discriminatory effects of the EU visa policy and, more generally, it impacts on the cooperation with third countries within the EU General Approach to Migration and Mobility.
\end{abstract}




\section{Keywords}

Common Code on Visa - visa facilitation - readmission - GAMM - border management - discrimination

\section{Setting the Background: Border Management and Cooperation with Third Countries}

To keep control over who enters their territory, States have introduced border checks and adopted border management policies. Since the establishment of the Schengen area, ${ }^{1}$ border management has been having momentum within the European Union (EU) and has been contributing to the Global Approach to Migration and Mobility (GAMM), the overarching political framework of the EU external migration and asylum policy aimed to establish and consolidate the cooperation with third countries on these policy areas. ${ }^{2}$

The 2001 European Council of Laeken triggered a political discussion around the Integrated Border Management (IBM). ${ }^{3}$ The concept found a legal formalization in Article 77 of the Treaty on the Functioning of the European Union $(\mathrm{TFEU})^{4}$ and more recently a more operational qualification in the Regulation establishing the European Border and Coast Guard (Frontex), the Agency

1 Agreement between the Governments of the States of the Benelux Economic Union, the Federal Republic of Germany and the French Republic on the gradual abolition of checks at their common borders, Schengen Agreement, 14 June 1985, and Convention Implementing the Schengen Agreement of 14 June 1985 between the Governments of the States of the Benelux Economic Union, the Federal Republic of Germany and the French Republic, on the Gradual Abolition of Checks at their Common Borders (Schengen Implementation Agreement), 19 June 199o.

2 Council of the EU, Global Approach to Migration: Priority Actions focusing on Africa and the Mediterranean, Council Conclusions, 17 December 2005, 15914/05; see also European Commission, Global Approach on Migration and Mobility, 18 November 2011, сом(2011)743 final. For references see in particular T. Strik (2017). The Global Approach to Migration and Mobility, 5(2) Groningen Journal of International Law, 311-328, at $322 \mathrm{ff}$.

3 European Council, Conclusions of the Presidency, Laeken, 14-15 December 2001. For an overview about the origin and understanding of the concept see P. Hobbing (2005). Integrated Border Management at the EU Level, Centre for European Policy Studies (CEPS) Working Document No. 227, Brussels: CEPS, available at: <https://www.ceps.eu/down load/publication/?id=5181\&pdf=1254.pdf $>$. For more extensive references see especially V. Moreno-Lax (2016). Accessing Asylum in Europe. Extraterritorial Border Controls and Refugee Rights under EU Law, Oxford: Oxford University Press, $3 \mathrm{ff}$.

4 Consolidated version of the Treaty on the Functioning of the European Union (TFEU), [2016] OJ C2O2/1, Art 77 (1) c). 
tasked with promoting, coordinating and developing European border management in line with the Charter of fundamental rights of the $\mathrm{EU}^{5}$ and the concept of Iвм. ${ }^{6}$ Amongst the different components of IBM, this Regulation mentions a better cooperation with third countries, 'focusing in particular on neighbouring countries and on those third countries which have been identified through risk analysis as being countries of origin and/or transit for illegal immigration.' ${ }^{7}$ According to Article 77 TFEU, one of the IBM building blocks is the common policy on visas, which allows to control who can have access to the Schengen area for short stays that do not exceed three months over any six-month period, thereby such a policy has been referred to as 'policing at a distance $^{8}$ or 'bordering from abroad'. 9

As a counterbalance, the readmission policy ensures that third country nationals, who do not or no longer fulfil the entry or residence conditions applicable in the territory of the requesting EU Member State, are readmitted in a requested third country. ${ }^{10}$ The major challenge to the EU is, therefore, to obtain full cooperation of third countries on the readmission of their nationals. The country of origin is, in fact, often far from willing to readmit its own nationals, especially for economic reasons, including the revenues generated by migrants' remittances. ${ }^{11}$

These two policies, on visa and readmission respectively, have been always considered as interconnected as regards the cooperation with third countries. ${ }^{12}$ EU visa facilitation usually constitutes a tool to convince third countries to sign readmission agreements. For the first time a clear link between visa facilitation

5 Charter of Fundamental Rights of the European Union, [2000] oj C 364/1.

6 See Art 3, Regulation (EU) 2019/1896 of the European Parliament and of the Council of 13 November 2019 on the European Border and Coast Guard and repealing Regulations (EU) No 1052/2013 and (EU) 2016/1624, OJ [2019] L295/1-131, Art 10.

7 Ibid., Art 3 g).

8 D. Bigo and E. Guild (2005). Policing at a Distance: Schengen Visa Policies, in: D. Bigo and E. Guild, Controlling Frontiers: Free Movement Into and Within Europe, Aldershot: Ashgate, $233-263$, at 233 .

$9 \quad$ Moreno-Lax (n 3), $81 \mathrm{ff}$.

10 See N. Coleman (2009). European readmission policy: Third country interests and refugee rights, Leiden: Brill/Nijhoff, for the first systematic study on the EU readmission policy.

11 As emphasized by F. Trauner and I. Kruse (2008). EC Visa Facilitation and Readmission Agreements: A New Standard EU Foreign Policy Tool?, 1o European Journal of Migration and Law, 411-438, at 431, 'many families in developing third countries depend upon money transfer from relatives who work abroad irregularly' See also G. Noll (1999). Rejected Asylum Seekers: The Problem of Return, 37 International Migration, 267-288.

12 J. Gromovs (2011). EC visa facilitation agreements and readmission agreements - state of play and future perspectives, in: M. Maes, M-C. Foblets, Ph. De Bruycker (eds), External Dimensions of EU Migration and Asylum Law and Policy, Brussels: Bruylant, 221-249. 
and readmission was made in the negotiations with Russia and Ukraine, when visa facilitation was used as an incentive to negotiate on readmission. ${ }^{13}$ While past research has already shed some light on the link between visa facilitation and readmission agreements, ${ }^{14}$ it is crucial to reconsider such a connection in the light of the recent reform of the Common Code on Visa (CCV) $)^{15}$ and the renewed approach to conditionality, which is permeating the whole EU migration policy at least since the 2015 European Agenda on Migration. ${ }^{16}$

As has been highlighted, the revised Visa Code 'integrates EU visa policy even more closely with the EU's external migration control policy, providing for incentives and sanctions for non-EU countries which respectively cooperate or fail to cooperate on readmission.17 To this extent, a new mechanism has been specifically designed. ${ }^{18}$ The revised CCV gives a new turn of the screw to cooperation on readmission, by providing the European Commission with the mandate to propose specific restrictive measures related to visa processing and visa fee in case of a lack of cooperation on readmission. While questioning its effectiveness, this article explains how this new mechanism can raise serious legal concerns that will especially affect the citizens of third countries. More specifically, it is argued that this reform accentuates the discriminatory effects of the EU policy on visa, traditionally criticized for the 'passport categorization' of people on the basis of their nationality. ${ }^{19}$

To pursue this goal, the major tenets and the alleged discriminatory nature of the EU visa policy and its legal framework will be unpacked; next, the analysis will shift to the interconnection between visa facilitation and readmission

13 Trauner and Kruse (n 11), 415.

14 See especially G. Papagianni (2013). Forging an External EU Migration Policy: From Externalisation of Border Management to a Comprehensive Policy?, 15 European Journal of Migration and Law, 283-299.

15 Regulation (EU) 2019/1155 amending Regulation (EC) No 810/2009 establishing a Community Code on Visas (Visa Code) [2019] oJ L188/1.

16 European Commission (2015). A European Agenda on Migration, Сом(2015) 240 final, 13 May 2015, sec III. See also European Commission, Communication to the European Parliament, the European Council, the Council and the European investment bank on establishing a new Partnership Framework with third countries under the European Agenda on Migration, сом(2016) 385 final, 7 June 2016.

17 S. Peers (2019). The revised EU visa code: controlling EU borders from a distance, $E U$ Law Analysis, 17 April 2019, available at: <http://eulawanalysis.blogspot.com/2019/o4/the -revised-eu-visa-code-controlling-eu.html >.

18 Regulation (EU) 2019/1155, Art 25a.

19 E. Guild and S. Carrera (2013). EU borders and their controls: preventing unwanted movement of people in Europe?, CEPS Essay No. 6, Brussels: CEPS, available at: <https://www .ceps.eu/system/files/No\%206\%2oEU\%2oBorders\%2oand\%2otheir\%2oControls\%2o revised.pdf $>$. 
agreements in the existing mobility partnerships, discussing a paradigm of conditionality which has been progressively replacing positive incentives, such as visa liberalization, with restrictive visa measures, resulting in a further form of discrimination. It is argued that the reform of the CCV can be situated in continuity with such an approach. Nonetheless, this reform rests on a more punitive shift, reiterated even by the recent New Pact on Migration and Asylum, ${ }^{20}$ that worsens the discriminatory nature of the EU visa policy and can be explained with the limited degree of cooperation achieved within the existing mobility partnerships. Ultimately, the article concludes that a principled cooperation with third countries in the framework of the GAMM can be linked with a transparent reform of the criteria used to determine which countries are subject to the obligation for their nationals to have a visa to enter the Schengen area.

The EU Visa Policy and Its Discriminatory Legal Design

One of the primary instruments to implement the GAMM is the visa policy. Before the Treaty of Maastricht, the issuance of visas for third country nationals was limited to those who were family members of a national of the European Community (EC) working in another Member State. This was essentially due to the different nature of the migratory flows to the EC, which were certainly more limited and mostly of economic nature, compared to the recent influx of forced migrants. ${ }^{21}$ Accordingly, the legal framework contained hortative provisions for Member States to facilitate the issuance of a visa in favour of these family members. ${ }^{22}$

20 European Commission, Communication to the European Parliament, the Council, the European Economic and Social Committee and the Committee of the Regions, New Pact on Migration and Asylum, сом(2020) 6o9 final, 23 September 2020, 21-22.

21 See C. van Mol and H. de Valk (2016). Migration and Immigrants in Europe: A Historical and Demographic Perspective, in: B. Garcés-Mascareñas and R. Penninx (eds), Integration Processes and Policies in Europe, Heidelberg: Springer, 31-56, at 35.

22 Council Directive 68/360/EEC of 15 October 1968 on the abolition of restrictions on movement and residence within the Community for workers of Member States and their families [1968] oJ L257/ 13-16, Art 3 (2). The Court of Justice, Regina $v$ Stanislaus Pieck, Case 157/7, [1980] ERC 271, para. 10, had the opportunity to clarify that for the purposes of such a provision an entry visa or equivalent requirement covers 'any formality for the purpose of granting leave to enter the territory of a member state which is coupled with a passport or identity card check at the frontier, whatever may be the place or time at which that leave is granted and in whatever form it may be granted.' For a systematic approach to 
It was only after the establishment and implementation of the Schengen agreements and the progressive codification of a specific competence for the EU in the fields of border checks, asylum and immigration since the Treaty of Amsterdam, ${ }^{23}$ that visa fell to be regarded as a more structural component of the general approach to the admission of third country nationals into the Schengen territory. This resulted in a regulatory framework aiming to harmonise the rules for the issuance of short stay visas allowing third country nationals to arrive at the border of the issuing state and, subject to further checks, to enter the State's territory and stay for a period of time. ${ }^{24}$

The visa policy contributes to define the legal contours of the GAMM, which is supported by a plethora of political, legal and financial instruments. ${ }^{25}$ The legal framework on visa is regarded as a set of harmonised rules governing different elements, including: (I) the common list of countries whose nationals require a visa to travel to the EU and those who are exempt from that requirement; (II) the Visa Code establishing the procedures and conditions for issuing short-stay visas; (III) the uniform format for the visa sticker; and (IV) the Visa Information System (VIS), in which all visa applications and Member States' decisions are recorded, including applicants' personal data, photographs and fingerprints.

Such a framework has evolved in a scattered way, this is why the visa acquis has been described as 'abundant, fragmented, and dispersed' with its origins based both in the Schengen cooperation and in the institutional activity within the European Community. ${ }^{26}$ An attempt to codify a more coherent legal regime resulted in the adoption of the Common Code on Visa by Regulation 810/2009 (CCV). This was adopted to establish 'the procedures and conditions for issuing visas for transit through or intended stays in the territory of the Member States not exceeding three months in any six-month period., ${ }^{27}$

the EU Visa policy see A. Meloni (2006). Visa Policy within the European Union Structure, Heidelberg: Springer.

23 Treaty of Amsterdam amending the Treaty on European Union, the Treaties establishing the European Communities and certain related acts, [1997] oJ C340/1-144, art 63 . See A. Meloni (2005). The development of a common visa policy under the Treaty of Amsterdam, 42 Common Market Law Review, 1357-1381.

24 For further references see A. Meloni (2009).The Community Code on Visas:Harmonization at last?, 34 European Law Review, 671-695.

25 Strik (n 2), 316.

26 Moreno-Lax (n 3), 83.

27 Art 1(1) Regulation (EC) No 810/2009 of the European Parliament and of the Council of 13 July 2009 establishing a Community Code on Visas (Visa Code), [2009] oJ L243/1. 
Such a Regulation, which replaced the previous legislation, has been recently amended by Regulation 2019/1155 that is applicable since 2 February 2020. ${ }^{28}$

The CCV is complemented by another two instruments: Regulation 2018/1806 that contains a common list of countries whose citizens must have a visa when crossing the external borders ('black list') and a list of countries whose citizens are exempt from that requirement ('white list'); ${ }^{29}$ and Regulation $767 / 2008$ on the Visa Information System (vis), which defines the purpose and functionalities of the computerised system aimed at facilitating the exchange of data between EU Member States and associated countries applying the common visa policy. ${ }^{30}$ No regulatory framework exists for long-term visas at the EU level nor for humanitarian visas aimed at guaranteeing safe access to the Schengen territory for third country nationals in need for international protection. As recently confirmed by the Court of Justice of the EU (CJEU), the competence to adopt humanitarian visas falls 'solely within the scope of national law'. 31 Interestingly, in the aftermath of the migratory emergency of 2015, during the negotiation on the first Commission's proposal to revise the Visa Code, ${ }^{32}$ the European Parliament had suggested that 'the possibility to apply for a European humanitarian visa directly at any consulate or embassy of the Member States should be established' within the revised $\mathrm{CCv}^{33}$ The proposal did not take off, owing to the Council's strong opposition, and it was not included in the final Commission's proposal to revise the CcV.

28 Regulation 2019/1155, Art 3(2).

29 Regulation (EU) 2018/1806 of the European Parliament and of the Council of 14 November 2018 listing the third countries whose nationals must be in possession of visas when crossing the external borders and those whose nationals are exempt from that requirement, [2018] oJ L3O3/39-58.

30 Regulation(EC) No $767 / 2008$ of the European Parliament and of the Council of 9 July 2008 concerning the Visa Information System (vis) and the exchange of data between Member States on short-stay visas (VIS Regulation), [2008] oJ L218/6o. This Regulation is under a process of revision, see European Commission, Proposal for a Regulation of the European Parliament and of the Council amending Regulation (EC) No $767 / 2008$, Regulation (EC) No 810/2009, Regulation (EU) 2017/2226, Regulation (EU) 2016/399, Regulation Xx/2018 [Interoperability Regulation], and Decision 2004/512/EC and repealing Council Decision 2008/633/JHA, СOM(2018) 302 final.

31 See in this regard Court of Justice of the EU (CJEU), C-638/16 PPU, X and Xv État belge, 7 March 2017, para. 44.

32 European Commission, Proposal for a Regulation of the European Parliament and of the Council on the Union Code on Visas (Visa Code) (recast) Сом(2014) 16o final, 1 April 2014.

33 European Parliament, Committee on Civil Liberties, Justice and Home Affairs (Rapporteur: Juan Fernando López Aguilar), Report on the proposal for a regulation of the European Parliament and of the Council on the Union Code on Visas (Visa Code) (recast), A8-0145/2016, 22 April 2016, proposed amendment for recital 26. 
It is worth mentioning that the Court of Justice has obtained full jurisdiction on all the measures adopted under Title $\mathrm{V}$ of the TFEU. Before the entry into force of the Lisbon treaty, in December 2009, the jurisdiction of the Court on visas, asylum, immigration and other policies related to free movement of persons was rather limited. In its ruling in Georgescu, in fact, the Court of Justice stated that, on the basis of former Article 68 (1) TEC, it lacked jurisdiction to interpret the Visa Regulation on a preliminary ruling from a national court that was not a court of last instance. ${ }^{34}$ The Lisbon Treaty repealed former Article 68 TEC thereby removing those restrictions on the jurisdiction of the Court to give preliminary rulings. Even though the case law on visa is still rather limited, this is a significant reform, as it provided for increased uniformity in the application of the legal framework and enhanced judicial protection for individuals. The Hassani judgment of 2017 on the relevance of the right to appeal against refusal of visa applications confirms the potential of the Court's interpretation of the EU visa acquis. ${ }^{35}$

The EU visa policy has been traditionally criticized for being discriminatory, ${ }^{36}$ as this body of law divides third country nationals in two general categories, including those who need a visa to enter the Schengen territory ('black list') and those who do not ('white list'). Such a divide has sparked lively academic debates about the asymmetrical access to mobility in the Schengen area ${ }^{37}$ and the human blacklisting of the EU external border regime. ${ }^{38}$

As has been emphasized, in fact, this form of 'passport categorization' has been impacting on the overall perception of third country nationals in the EU, with some non-EU citizens that are seen with suspicion rather than as legitimate travellers, ${ }^{39}$ and has confirmed the 'general use of visa requirements as a tool for immigration control. ${ }^{40}$ Some criticism has been also shed on the fact that the inclusion of a country into the 'black list' was mostly depending on the

34 CJEU, C-51/o3 PPU, Georgescu, 31 March 2004. For further details see Meloni (n 22), 96.

35 CJEU, C-403/16, El Hassani, 13 December 2017. For further references in this regard see W. Piątek (2019). The right to an effective remedy in European law: significance, content and interaction, 6 China-EU Law Journal, 163-174.

36 See in particular R. Cholewinski (2002). Border and Discrimination in the European Union, Brussels: Migration Policy Group, 21, available at: <https://www.migpolgroup.com/_old/ wp-content/uploads/2016/10/152.bordersandDiscrimination_exec_summary_01.o2.pdf $>$.

37 See e.g. C. Finotelli and G. Sciortino (2013). Through the gates of the fortress: European visa policies and the limits of immigration control, 14 Perspectives on European Politics and Society, $80-101$.

38 H. van Houtum (2010). Human blacklisting: The Global Apartheid of the EU's external Border Regime, 28 Environment and Planning D: Society and Space, 957-976.

39 Guild and Carrera (n 19).

$40 \quad$ Finotelli and Sciortino (n 37), 84. 
levels of irregular migrants or asylum seekers from that particular country registered in the previous years ${ }^{41}$ From this perspective, the visa policy responds to the increasing tendency to the securitization of the Schengen area and constitutes an essential component of the externalization of IBM, by which border controls are 'performed anticipatorily beyond the external frontiers of the EU by authorities posted in third countries, including member States' embassies and consulates' personnel.'42 The European Commission itself has confirmed that the visa policy is a 'vital tool in preventing irregular migration towards the European Union and potential threats to its security'.43 Nonetheless, it is difficult to evaluate to which extent the provisions of the CCV have contributed to preserving the security of the Schengen external borders, since the full deployment of the VIS, both at consular posts worldwide and at Schengen border crossing points, was completed only in $2016 .{ }^{44}$

The Commission's approach to the visa policy as a migration management tool has been even more recently reiterated in its latest Proposal to recast the $\mathrm{CCV}^{45}$ In this regard, the revision was mostly oriented to the facilitation of visa procedures or to the clarification and streamlining of existing provisions, on the one hand, and to establishing a legal link between visa policy and third countries' cooperation on readmission of irregular migrants, on the other hand. This reflects the position already expressed by the Council in its mandate to negotiate the first Commission's proposal to revise the $\mathrm{CCV}^{46}$ and that favoured 'the establishment of a link between third-countries' cooperation

\footnotetext{
41 Ibid., 85.

42 Moreno-Lax (n 3), 82. See also J. Huysmans (2000). The European Union and the securitization of migration, 38 Journal of Common Market Studies 751-777.

43 European Commission, Evaluation of the implementation of the European Community's visa facilitation agreements with third countries, Commission Staff Working Document SEC (2009)1041 final. See also the most recent Impact Assessment, European Commission, Staff Working Document Impact Assessment Accompanying the Document Proposal for a Regulation of the European Parliament And of the Council Amending Regulation (EC) No 810/2009 establishing a Community Code on Visas (Visa Code), swD/2018/o77 final.

$44 \operatorname{com}(2018) 302$ final.

45 Proposal for a Regulation of the European Parliament and of the Council amending Regulation (EC) No 810/2009 establishing a Community Code on Visas (Visa Code), $\operatorname{COM}(2018) 252$ final. See, for preliminary considerations on the negotiations N. Vavoula (2018). Of Carrots and Sticks: A Punitive Shift in the Reform of the Visa Code, $E U$ Immigration and Asylum Law and Policy, 5 September 2018, available at: <http://eumigra tionlawblog.eu/of-carrots-and-sticks-a-punitive-shift-in-the-reform-of-the-visa-code/>.

46 Council of the EU, Mandate for negotiations with the European Parliament, 8435/16, 29 April 2016.
} 
on readmission and rules on visa facilitation, ${ }^{47}$ As will be highlighted in the following section, this approach was especially followed in the association process with the Western Balkan countries, in the light of a mechanism triggering a temporary suspension of the exemption from the visa requirement in case of 'a decrease in cooperation on readmission'. 48

Visa facilitation and cooperation on readmission are not directly regulated in the CCV but they are the object of separate agreements between the EU and third countries within broader Mobility Partnerships. ${ }^{49}$ As will be discussed in greater detail in Section 4, the recent amendment to the CCV limits itself to establish that in case of lack of cooperation by certain third countries to readmit those of their nationals in an irregular situation, 'a restrictive and temporary application of certain provisions' of the CCV will be applied.50 This consolidates the "stick and carrot" practice of the EU to negotiate visa facilitation agreements with third neighbouring countries in exchange for readmission agreements. ${ }^{51}$ Such a practice, as will be highlighted, has even furthered the discriminatory nature of the EU visa law's architecture with an overly classification and selectivity of third country nationals. However, as illustrated in the next session, this practice within existing mobility partnerships shows that the incentive of visa liberalization has not been sufficient to ensure more cooperation on readmission. This has determined a shift from a 'more for more' to a 'less for less' approach to cooperation with third countries, ${ }^{52}$ in which positive incentives, such as visa liberalization, have been progressively accompanied by more stringent conditionality measures linked with cooperation on readmission. On a whole, this approach has increased the discriminatory effects of the EU visa policy without ensuring a more effective cooperation on readmission.

47 E. Guild (2019). Amending the Visa Code: Collective Punishment of Visa Nationals?, EU Immigration and Asylum Law and Policy, 10 May 2019, available at: <http://eumigration lawblog.eu/amending-the-visa-code-collective-punishment-of-visa-nationals/>.

48 Regulation (EU) 2018/1806, Art 8(2)c.

49 For further references see E. Collett and A. Ahad (2017). EU Migration Partnerships: A Work in Progress, Report, Brussels: Migration Policy Institute, December 2017, available at: $<$ https://www.migrationpolicy.org/research/eu-migration-partnerships-work-progress>. See also S. Brocza and K. Paulhart (2015). EU mobility partnerships: a smart instrument for the externalization of migration control, 15 European Journal of Futures Research, 2-7.

$5^{\circ}$ Regulation (EU) 2019/1155, recital 13 .

$5^{1} \quad$ Vavoula (n 45).

$5^{2} \quad$ Strik (n 2), 322. 


\section{From Mobility Partnerships to the European Travel Information and Authorisation System: A Further Visa Selectivity?}

The practice to offer EU mobility partnerships to third counties is part of a strategy aimed at enhancing border and migration control, thereby these partnerships are considered as 'the most innovative and sophisticated tool to date of the Global Approach to Migration, ${ }^{53}$ They constitute the political framework in which specific visa facilitation agreements and readmission agreements, inter alia, are negotiated in parallel, pursuing a conditionality approach in which visa liberalization is considered as an exchange currency for cooperation on readmission. The reform of the Visa Code can be situated in continuity with such an approach, but it reflects a more punitive shift, which can be explained with the limited degree of cooperation on readmission achieved with existing mobility partnerships. ${ }^{54}$

Accordingly, this section argues that, while creating some more flexibility within the EU visa policy, these mobility partnerships as well as the future European Travel Information and Authorisation System (ETIAS) ${ }^{55}$ worsen the EU visa selectivity without any significant results as to cooperation on readmission.

Since 2007 the EU has concluded agreements with third countries to facilitate the issuance by a Member State of authorizations to the nationals of that specific third country for transiting through or an intended stay in the territory of the EU of a duration of no more than three months in any six-month period from the date of first entry into the territory of the EU States. ${ }^{56}$ These agreements can be distinguished in two generations.

A first generation of visa facilitation agreements has been negotiated with Western Balkan countries and concluded in 2008. All these countries have been progressively included in the list of third countries whose nationals

53 European Commission, Staff Working Document 'Mobility partnerships as a tool of the Global Approach to Migration' SEC(2009)1240/F1, 18 September 2009, 4.

54 European Commission, Communication from the Commission to the European Parliament and the Council, Evaluation of EU Readmission Agreements, сом(2011) 76 final, 23 February 2011.

55 Regulation (EU) 2018/1240 of the European Parliament and of the Council of 12 September 2018 establishing a European Travel Information and Authorisation System (ETIAS) and amending Regulations (EU) No 1077/2011, (EU) No 515/2014, (EU) 2016/399, (EU) 2016/1624 and (EU) 2017/2226 (ETIAS Regulation) [2018] OJ L236/1-71.

56 A list of visa facilitation agreements is available on the official webpage of the European Commission's DG Home at: <https://ec.europa.eu/home-affairs/what-we-do/policies/bor ders-and-visas/visa-policy_en>. 
are exempt from the visa requirement. ${ }^{57} \mathrm{~A}$ second generation of agreements has been mostly negotiated with East European States, including Armenia, Azerbaijan, Georgia, Moldova and Ukraine, and concluded between 2011 and 2014. It must be mentioned that a visa facilitation agreement was concluded with Russia in 2007 and another one with Cape Verde in $2014,{ }^{58}$ while a visa facilitation agreement was more recently signed with Belarus in January 2020. ${ }^{59}$ These generations of agreements constitute a specific component of the strategy underpinning the European Neighbourhood Policy (ENP), which was launched in 2003 and revised in 2015 to avoid the emergence of new dividing lines between the enlarged EU and its Eastern and Southern neighbours. ${ }^{60}$ At present, only Georgia, Moldova and Ukraine have been included in the list of third countries whose nationals are exempt from the visa requirement. ${ }^{61}$

Visa facilitation has become 'the major compensation matter introduced by third countries in negotiations with the EU'62 while negotiating readmission agreements. These establish the procedures for the return of persons (own and third country nationals or stateless persons) in irregular situation to the EU or the third country partner. ${ }^{63}$ Even though visa facilitation has been considered as functional to an effective readmission policy, ${ }^{64}$ this makes the object of separate legal instruments. Visa facilitation agreements are seen as instrumental to the effective negotiation of readmission agreements between the EU and third countries. Despite being criticized, owing to the lack of reliable methods

57 See Regulation (EU) 2018/1806, Annex II.

58 Negotiations started in 2001 also with Hong Kong, Macao, Sri Lanka, Morocco, and Pakistan; with Turkey in 2003; with China in 2004; with Algeria in 2005.

59 Following the signature, the agreement, available at: <https://www.consilium.europa .eu/en/press/press-releases/2020/05/27/belarus-eu-concludes-agreements-on-visa -facilitation-and-readmission/>, will be submitted to the European Parliament for consent. The Council will then be able to formally conclude the ratification of both agreements. A ratification procedure is also required on the Belarusian side, through approval from Belarus National Assembly.

6o See in this regard, amongst the others, S. Poli (ed.) (2016). The European Neighbourhood Policy - Values and Principles, Abingdon: Routledge.

61 See Regulation (EU) 2018/1806, Annex II.

62 Trauner and Kruse (n 11), 413. See also A. Meloni (2013). EU Visa and Border Control Policies: What roles for security and reciprocity?, in: D. Bigo, S. Carrera and E Guild (eds), Foreigners, Refugees or Minorities? Rethinking people in the context of border controls and visas, Aldershot: Ashgate, 151-169.

63 See generally in this regard Coleman (n 10), 2; see also M. Giuffré (2020). The Readmission of Asylum Seekers under International Law, Oxford: Hart Publishing.

64 See Council of the EU, 'The Hague Programme: strengthening freedom, security and justice in the European' [2005] oJ $\mathrm{C}_{53} / 1$. 
to ascertain the level and effectiveness of implementation, ${ }^{65}$ the impact of readmission agreements has been used by the European Commission as a criterion for the determination of those countries whose nationals would need a visa to enter the Schengen territory. ${ }^{66}$

As is known, since 1999, with the entry into force of the Amsterdam treaty, the EC gained competence also in concluding readmission agreements. This competence is now clearly established by the Treaty of Lisbon in Article 79 (3) T FEU. ${ }^{67}$ It is also worth stressing that, apart from readmission agreements, specific readmission clauses are also included in agreements which the EU concludes with third countries on other policy issues. ${ }^{68}$ This confirms how over the years the issue of readmission of third country nationals in an irregular situation has become a more structural policy issue as well as an example of the conditionality approach pursued by the EU in the cooperation with third countries.

Negotiations on readmission agreements at the European level started in 2001. ${ }^{69}$ Following the invitation set in the Stockholm Programme that the 'Council should define a renewed, coherent strategy on readmission ..., taking into account the overall relations with the country concerned, including a common approach towards third countries that do not cooperate in readmitting their own nationals, ${ }^{70}$ the first phase of the EU readmission policy was subject to a process of re-evaluation. ${ }^{71}$ Accordingly, in 2011, on the basis of this evaluation on the concluded and under negotiation readmission agreements,

65 See in particular Cholewinski (n 36$)$. See also J-P. Cassarino, Dealing with unbalanced reciprocities: Cooperation on readmission and implications, in: J-P. Cassarino (ed.) (2010). Unbalanced reciprocities: Cooperation on readmission in the Euro-Mediterranean area, Washington: Middle East Institute, 1-29.

66 European Commission, Proposal for a Council Regulation listing the third countries whose nationals must be in possession of visas when crossing the external borders and those whose nationals are exempt from that requirement, СОМ (2000) O27 final, [2000] OJ C $177 \mathrm{E} / 66-69$.

67 Art 79 (3) TFEU clearly states: 'The Union may conclude agreements with third countries for the readmission to their countries of origin or provenance of third-country nationals who do not or who no longer fulfil the conditions for entry, presence or residence in the territory of one of the Member States.'

68 Coleman (n 10), 2.

69 As reported in Trauner and Kruse (n 11), at 415, negotiations started in 2001 with Hong Kong, Macao, Russia, Sri Lanka, Morocco, and Pakistan. See also A. Roig and T. Huddleston (2007). EC readmission agreements: A Re-evaluation of the Political Impasse, 9 European Journal of Migration and Law, 363-387.

70 Council of the EU, The Stockholm Programme, 'An open and secure Europe serving and protecting citizens', [2010] C115/o1, para. 6.1.6.

$71 \quad \operatorname{com}(2011) 76$ final. 
the Commission launched a strategy for a renewed EU readmission policy. Such a strategy proposes that incentives for cooperation on readmission with third countries will be part of a coherent mobility package to be offered to third countries and that the readmission policy will be embedded in the overall external relations policies of the EU. ${ }^{72}$ This consolidated what has been defined as the 'more for more' approach, according to which 'negotiations with third countries on migration control include various positive incentives for transit countries, ${ }^{73}$ visa liberalization or facilitation.

Visa facilitation has, in fact, become a distinct feature of the new readmission policy. While readmission agreements have been negotiated with a differentiated range of third counties, ${ }^{74}$ including States that are not involved in the ENP, such as Honk Kong, Sri Lanka or Pakistan, parallel negotiations on readmission and visa facilitation have been officially conducted since 2001 with Russia and then Ukraine. However, the most successful examples can be drawn from the experiences with the countries in the Western Balkans. ${ }^{75}$ The European Commission also emphasized that the countries' capacity to ensure correct and effective implementation of the readmission agreements will also be taken into consideration in view of future visa liberalization regime. ${ }^{76}$

These agreements are especially used as a migration management tool. Nonetheless, despite the positive incentive of visa facilitation, the literature has recurrently questioned the effectiveness of these instruments, ${ }^{77}$ as to the cooperation with third countries on readmission. The 'more for more' approach proved inadequate, also due to the limited positive incentives, as the existing mobility partnerships have paid less attention to relevant aspects of the migrants' integration process, such the recognition of academic of professional titles or family reunification in the destination countries. ${ }^{78}$

Moreover, the readmission of migrants is a multifaceted and complex process and has been proved always very challenging. Such complexity is also linked with the personal scope of these agreements, which usually cover at least three categories of persons. These include: (a) third country nationals

$72 \quad$ Ibid., 14.

73 Strik (n 2), 314 .

74 A list of EU readmission agreements is available on the official webpage of the European Commission's DG Home at: <https://ec.europa.eu/home-affairs/what-we-do/policies/ irregular-migration-return-policy/return-readmission $>$.

75 Trauner and Kruse (n 11), 416.

76 European Commission, Staff Working Document accompanying the Communication from the Commission to the European Parliament and the Council Western Balkans: enhancing the European perspective, Сом(2008) 127 final, 5 March 2008.

77 Trauner and Kruse (n 11), at 434.

78 For further references see Collett and Ahad (n 49). 
who are rejected asylum seekers, namely individuals whose claims for international protection were considered unfounded or inadmissible; (b) third country nationals who are irregular migrants, who 'owing to illegal entry or the expiry of his or her visa, lacks legal status in a transit or host country'; ${ }^{\prime}$ or (c) asylum seekers and or refugees that can be protected in the State-Party to the readmission agreements, even if they are not nationals of the concerned State-Party. This particular category of people is expected to be especially addressed in future readmission agreements, based on the model established by the controversial EU-Turkey deal of March 2016. ${ }^{80}$ This is the first instrument, by which the EU, informally if not directly, ${ }^{81}$ endorsed the practice to outsource protection responsibilities to third countries, which has been recently recognized officially as a political priority by the European Council. ${ }^{82}$

Owing to the low return rate, the European Commission itself admitted that the 'results remain disappointing.' ${ }^{83}$ The European Court of Auditors, which is currently preparing a Report to be published in 2021 to evaluate whether the set measures adopted by the European Commission, especially after 2015, have improved cooperation with priority third countries, confirmed that 'less than $40 \%$ of the irregular migrants ordered to leave the EU actually return to their home country or a third country' ${ }^{4}$ Despite the relative positive results achieved with the Western Balkan and Eastern Partnership countries, cooperation on readmission remains a challenge, especially as regards the readmission

79 The International Organization for Migration (Iом) (2004) Glossary on Migration, 34, confirmed that the term 'applies to migrants who infringe a country's admission rules and any other person not authorized to remain in the host country'.

80 Council of the EU, EU-Turkey Statement (18 March 2016), Press release, available at: $<$ http://www.consilium.europa.eu/en/press/press-releases/2016/o3/18-eu-turkey-state ment/>. See for references N. Tezcan-Idriz (2018). The EU-Turkey statement or the refugee deal: the extra-legal deal of extraordinary times?, in: D. Siegel and V. Nagy (eds), The migration crisis?: criminalization, security and survival, Amsterdam: Eleven Publishing, $61-84$.

81 See General Court, T-192/16, T-193/16, T-257/16, NF, NG and NM v. European Council, Order of 28 February 2017, reporting the argument of the European Council which claimed that "the term "EU" must be understood in this journalistic context as referring to the Heads of State or Government of the Member States of the European Union' (para. 57).

82 European Council, Presidency Conclusions, 28 June 2018.

83 European Commission, Communication to the European Parliament, the European Council and the Council, Progress report on the Implementation of the European Agenda on Migration, $\operatorname{COM}(2019) 481$ final, 16 October 2019, 'According to data reported to Eurostat, 478,155 persons illegally staying in the EU were ordered to leave in 2018 , and 170,380 were effectively returned to a third country'.

84 European Court of Auditors (ECA), Migrant returns and readmission to third countries probed by EU Auditor, Press Release, 28 July 2020, available at: <https://reliefweb.int/ report/world/migrant-returns-and-readmission-third-countries-probed-eu-auditors $>$. 
of third-country nationals. A progressive decrease in the return rate has been reported, in fact, by the European Commission with all countries involved in the partnerships. ${ }^{85}$ The visa suspension mechanism introduced in 2017 to strengthen the European Commission's competences as regards the monitoring of visa liberalization processes with third countries has not, therefore, delivered the expected results. The mechanism provided the European Commission with the twofold obligation of monitoring and reporting the continuous fulfilment of the visa liberalisation requirements, which were used to assess the appropriateness of granting visa free travel to a third country as a result of a successful conclusion of a visa liberalisation dialogue. This mechanism could be triggered by the European Commission also in case of an increasing refusal rate for readmission applications. ${ }^{86}$

Finally, while the Western Balkan and Eastern Partnership countries may constitute an example of the 'more for more' approach, it is not obvious that this approach can be successful if applied to countries where the incentives linked with an association process, including visa liberalization, cannot be available. These mobility partnerships interpret specific political priorities, first and foremost an association process aiming to full membership of the EU, and they aim to introduce special entry regimes for the nationals of the third countries involved in the mobility partnerships. ${ }^{87}$ Such a system of agreements introduces a further categorization on the basis of the nationality or a selective visa policy ${ }^{88}$ with the consequence of creating classes of privileged and less privileged third country nationals vis-à-vis the EU. These mobility partnerships, therefore, give rise to a complex coexistence of different schemes within the EU visa policy, in which the entry and stay of third country nationals in the $\mathrm{EU}$ is more dependent on the political relations between the EU and the third countries rather than on the actual personal circumstances of the individuals.

This framework becomes even more intricate with the establishment of the European Travel Information and Authorisation System (ETIAS), which is

85 See the European Commission's reports on implementation of benchmarks for Western Balkans and Eastern Partnership countries, 'Third Report under the Visa Suspension Mechanism' $\operatorname{COM}(2020) 325$ final, 10 July 2020, see also the accompanying Staff Working Document, SWD(2020) 132 final. For further references in literature see F. Trauner and E. Manigrassi (2014). When Visa-free Travel Becomes Difficult to Achieve and Easy to Lose: The EU Visa Free Dialogues after the EU's Experience with the Western Balkans, 16 European Journal of Migration and Law, 125-145.

86 See Regulation (EU) 2017/371.

87 See in this regard A. Pitrone (2018). Regimi speciali in materia di ingresso e soggiorno di cittadini di Paesi terzi nell'Unione europea, Naples: Editoriale Scientifica.

88 L. Laube (2019). The relational dimension of externalizing border control: selective visa policies in migration and border diplomacy, 7 Comparative Migration Studies, 1-22. 
expected to apply by the end of 2022 to third country nationals who do not have the obligation to apply for a visa to enter the Schengen area. Conceived to fulfil the objectives of the European Agenda on Migration and the European Agenda on Security, ${ }^{89}$ ETIAS is another instrument for border management that would add a layer of border control for the assessment of visa-free third country nationals arriving for a short stay. Such a sophisticated system is unduly selective and overly costly. As argued by Guild, a single system of pre-entry authorization applicable to all third country nationals could have avoided 'differential costs and discrimination on the basis of (third-country) nationality'. ${ }^{\prime 0}$ In fact, an ETIAS costs only 7 euros for individuals between the ages of 18 and 70 while it is free for persons under the age of 18 , or over $70 .{ }^{91}$

\section{From Selectivity to Punishment: The Legal Challenges beyond the Reform of the Common Code on Visas}

Great expectations have been put on the revision of the EU Visa Code, as an important additional tool, providing the EU with the possibility to adopt restrictive visa measures for third countries which do not sufficiently cooperate on readmission,92 in line with the priorities sketched in the 2015 Action Plan on Return ${ }^{93}$ and the Partnership Framework Communication of $2016 .{ }^{94}$

However, as will be delved into in the next sub-sections, this new turn of the screw on the cooperation on readmission in the revised CCV raises a number of legal issues that cast doubts as to whether this reform is a significant step in the right direction. The recent reform of the CCV reflects a paradigm shift from a 'more for more' to a 'less for less' approach resulting in a more restrictive and discriminatory system. As explained above, this reform confirms the limits and scant results in terms of cooperation on readmission of an approach based on incentives, such as visa liberalization. The relevant amendments have been

89 European Commission, Communication to the European Parliament, the Council, the Economic and Social Committee and the Committee of the Regions, 'The European Agenda on Security' Сом(2015) 185 final, 28 April 2015.

$90 \quad$ Guild (n 47).

$91 \quad$ ETIAs Regulation, Art 18.

92 Regulation (EU) 2017/371.

93 European Commission, Communication to the European Parliament and the Council, Action Plan on Return, сом(2015) 453 final, 9 September 2015.

94 European Commission, Communication to the European Parliament, the European Council, the Council and the European Investment Bank, on establishing a new Partnership Framework with third countries under the European Agenda on Migration, $\operatorname{com}(2016) 385$ final, 7 June 2016. 
agreed upon between the Council and the European Parliament and adopted on 20 June $2019 .{ }^{95}$

Nonetheless, while the effectiveness of the new turn of the screw on cooperation on readmission remains questionable, this reform of the CCV raises a number of legal concerns that stress the discriminatory nature of the EU visa policy and can eventually undermine the cooperation with third countries. These issues will be dealt with in detail, after a short overview of the main tenets of the reform.

\subsection{The New Mechanism for Cooperation on Readmission}

Two are the major changes introduced by the reform and they concern a procedural simplification for visa processing and a tighter cooperation on readmission. From the first point of view, new rules aim to streamline the procedures by extending to no more than six months before the start of the intended visit the deadline for third country nationals to lodge an application, in order to plan a journey in advance. ${ }^{96}$ In this regard, it is also established that a decision on the visa application should be taken without delay in justified individual cases of urgency and within 10 days instead of the former delay of 15 days. ${ }^{97}$ Such a procedural facilitation is nonetheless counterbalanced by an increase of 20 Euros in the visa fee (from 60 to 80 Euros). ${ }^{98}$

Secondly, and more importantly, the distinct feature of the revised CCV is its aim to contribute to improving cooperation with third countries on readmission by introducing a new mechanism for using visa processing as leverage. In this connection, it is crucial to shed light on the scope of new Article 25a on 'cooperation on readmission'. This is substantially the most relevant amendment to the $\mathrm{CCV}$ which, by integrating a system of incentives and sanctions for third countries, ${ }^{99}$ based on their degree of cooperation on readmission, transforms the EU visa policy in an even more powerful tool of migration control.

Pursuant to this new provision, the European Commission receives the mandate to assess, at least once a year, whether third countries cooperate on readmission. Such an assessment is based on a number of criteria. These include: the number of return decisions issued to persons from the third country in question; the number of actual forced return of persons as a percentage of the

95 For further detail on the recast process see Guild ( $\mathrm{n} 47$ ).

96 See amendment to Art 9 CCV. Formerly, applications had to be lodged no more than three months before the start of the intended visit.

97 See the joint combination of amendment to Art 23 (1) and new Art 25a (8) b) CCV.

98 See amendment to Art $16 \mathrm{ccv}$.

99 See in this regard Vavoula ( $\mathrm{n} 45)$. 
number of return decisions; the number of readmission requests; the level of practical cooperation in return procedures. Based on this assessment, if the third country is not considered as adequately cooperating, the Commission is under the obligation ('shall') to propose to the Council to adopt an implementing decision applying specific restrictive visa measures related to visa processing and, eventually, to the visa fee. On the contrary, if a country is found to be cooperating on readmission, the Commission may propose to the Council to adopt an implementing decision providing for either a reduction in the visa fee, a reduction in the time to decide on visa applications, or an increase in the period of validity of multiple entry visas, that allows the holder to travel repeatedly to the EU during the period of validity of the visa. ${ }^{100}$

The literal interpretation of the provision reveals the overall punitive shift of the reform, which in fact establishes an obligation for the European Commission to propose the adoption of restrictive measures in case of, inter alia, a lack of cooperation on readmission, while there is only a discretion to propose visa facilitation measures in case of a positive assessment of the cooperation with the third country. Apart from influencing the relationship between the EU and third countries, which are implicitly imposed to take over EU border control responsibilities, ${ }^{101}$ the mechanism under new Article 25a raises a number of issues that is worth analysing because they can affect directly the citizenry of these third countries. These issues concern especially the increased discriminatory effects of the mechanism under Article 25a, the ineffectiveness of the rationale behind such a mechanism and the overall direction of cooperation with third countries.

\subsection{Increased Discriminatory Effects}

The mechanism established by new Article 25a of the revised CCV concerns those countries, whose nationals need a visa when crossing the external borders with the EU. Admittedly, these are countries for which the incentive of visa liberalization does not work as an option in order to foster their cooperation on readmission. These countries are mostly in the African and Asian regions that over the last 20 years saw a progressive withdrawal of visa waiver agreements by the EU. ${ }^{102} \mathrm{By}$ the recent reform of the $\mathrm{CCV}$, as has been empha-

\footnotetext{
100 New Art 25a (5) CCV.

101 On this point see Laube (n 88).

102 In this connection, L. Laube and R. Heidler (2016). Democratic Centre, autocratic isolates: The changing field of international visa policies, 42 Journal of Ethnic and Migration Studies, 15, argue that 'one of the central points of the common EU visa policy was to (re)
} 
sised by Guild, the EU has pursued an approach that essentially results in a punitive shift, with nationals of these countries that do not cooperate on readmission being punished with doubled visa fees (from 80 euros to 120 or even 160 euros $)^{103}$ or exclusion from: (a) simplified visa application procedures; (b) waivers for holders of diplomatic and service passports; (c) the 15 day visa processing time; (d) access to multiple entry visas. ${ }^{104}$

Such a system of penalties is an expression of the 'less for less' approach, aiming to apply negative incentives to third-country cooperation, which is a characteristic of the most recent developments within the GAMM. ${ }^{105}$ The new mechanism is problematic because it does not only pass on the consequences of the government's inability to deal with readmission duties to citizens, but gives rise to discrimination on the basis of nationality within those States which are on the EU's visa black list.

As was highlighted in Section 2, the whole EU visa system has been accused of being discriminatory, ${ }^{106}$ to be even considered as 'global apartheid politics' ${ }^{\prime} 107$ As argued by Guild, the selectivity behind the EU visa policy indirectly tends to exclude those countries, 'the majority of whose population is either black or Muslim.'108 On the contrary, Den Heijer has argued that there is no evidence of a discriminatory intent in the EU visa policy, as the listing of countries whose nationals would be exempt from visa obligations (white list) rests on geopolitical, economic and cultural or historical ties with the EU or its Member States. ${ }^{109}$ This may be considered a compelling argument, especially in the light of a stream of European human rights case law that has opened up to possible indirect discrimination in the field of immigration, provided that this is justified by a legitimate aim, such as the protection of the labour market.110

introduce visa restrictions for countries with former colonial ties or close economic relations to only one of the EU member states'.

103 See amendment to Art $16 \mathrm{CCV}$.

104 On this point see also Guild (n 47).

105 Strik (n 2), 322.

106 Cholewinksi (n 36), 22.

107 Van Houtum (n 38), 957.

108 E. Guild (2001). Moving the Borders of Europe, Inaugural lecture, Publicaties Faculteit der Rechtsgeleerdheid, KU Nijmegen, 38 .

109 M. den Heijer (2018). Visas and Non-discrimination, 2o European Journal of Migration and Law, 470, $485 \mathrm{ff}$.

110 See European Court of Human Rights (ECtHR), Abdulaziz, Cabales and Balkandali v United Kingdom, Apps Nos 9214/80, 9473/81 and 9474/81, 28 May 1985. For further references see Den Heijer (n 107) 475 ff. For further references see F. Pennings (2013). 
Nevertheless, it is worth stressing that, pursuant to Article 21(1) of the Charter of Fundamental Rights of the EU, it is legitimate to expect that the prohibition of discrimination applies to all fields of EU law, including visa, asylum and immigration. In addition, the personal scope of Article 21(1) encompasses third country nationals, although no claims have been lodged yet before the EU Court of Justice. Regardless of the criteria used to (black)list the countries whose nationals need a visa to enter the Schengen territory, the reform of the CCV discriminates between individual cases owing to the political performance of the country of nationality. Another form of discrimination becomes visible with the coexistence of the visa system with the mentioned ETIAs. ${ }^{111}$ A visa is, in fact, much more expensive than the ETIAS, and its costs can even increase, as the revised CCV opens to the possibility for Member States to rely on external service providers that can collect visa applications if a Member State is neither present nor represented in the third country where the applicant is to lodge the application."112 Accordingly, nationals of low income third countries, who need a visa to enter the Schengen area, are required to pay very high fees, with the consequence of a further socio-economic discrimination. From this perspective, the reform of the CCV, therefore, confirms the trend to 'exclude or selectively include citizens from third countries' as well as 'the political use' of mobility'.113

\subsection{Unethical Blackmail}

The discriminatory effects of the revised CCV are not the only controversial aspect of the new provision under Article 25a. Ambiguities lay also in the criteria by which the European Commission will assess third countries' cooperation on readmission in order to trigger the mentioned mechanism.

These criteria insist on the track records of the cooperation on readmission and actual returns. This is especially problematic because, as illustrated by the last Frontex Risk Analysis, the ten most reported nationalities for return decision include nationals of countries that, because of the high level of political instability or a warfare situation, like in the case of Afghanistan or Syria, are not able to ensure an effective level of cooperation on readmission. ${ }^{114}$ Some

Non-Discrimination on the Ground of Nationality in Social Security: What are the Consequences of the Accession of the EU to the ECHR?, 9 Utrecht Law Review, 118-134.

111 Regulation (EU) 2018/1240.

112 Revise CCV, amendment to Art 8.

113 Laube (n 88).

114 Frontex (2020). Risk Analysis for 2020, Warsaw: Frontex, available at: <https://frontex .europa.eu/publications/frontex-releases-risk-analysis-for-2020-vpoTZ $>$. Within the ten 
of these countries, such as Syria or Iraq, are amongst the top nationalities of asylum seekers and recognized refugees in the EU. Apart from wondering if these criteria are ethically sound, one may even question their effectiveness. According to Frontex Reports, in fact, in 2019 a total of 71,163 forced returns were effectively operationalized, a number which confirms a slow but continuous decrease since 2016.115 The top ten nationalities of people subjected to forced return from the EU are Albanian, Moroccan, Algerian, Georgian, Tunisian, Ukrainian, Brazilian, Serbian, Moldovan and Russian. Of these nationalities, only Morocco, Algeria, Tunisia and Russia are subject to visa obligation, accordingly, the mechanism under Article 25a would be irrelevant for most of these countries which have been included in the list of third countries whose nationals are exempt from the visa requirement.

Such a scenario sheds light on the fact that a clear justification for the determination of those countries whose nationals are under the EU visa obligation is still missing. As has been argued, such a determination is mostly 'unchanged since the harmonization of visa policies by the Schengen States.'116 A comprehensive review by the European Commission is necessary and should go beyond considerations linked with the flow of irregular migrants or the rate of returns and readmission. It would require more attention to the individual cases rather than to the whole political performance of a third country. For long time, especially countries in the Global South, mainly African and Asian States, have been subject to the visa obligation. A review of this list of countries is, therefore, a matter of global justice ${ }^{117}$ and requires the European Commission to overstep reasons of mere political interest and to more carefully consider the potential for the whole architecture of EU immigration law to facilitate the issuance of visa for nationals of traditional countries of origin of migratory flows to the $\mathrm{EU}$, if there is evidence that they do not pose any risk of public order or security and do not constitute a threat of irregular immigration into the EU.

\subsection{Puzzling the Cooperation with Third Countries}

The link with readmission marked by the revised CCV will certainly influence the future use of visa facilitation agreements and readmission agreements.

most reported nationalities for return decisions in 2019, nationals of Albania, Pakistan, Syria, Algeria, Brazil and Turkey witnessed an increase of return decisions, while the number of Iraqis showed a decrease in comparison with the previous year.

115 Ibid., Annex Table 13.

116 Den Heijer (n 108), 487.

117 Ibid., 489. 
On the one hand, it might be argued that a permanent mechanism with incentives and sanctions can consolidate the trade-off between visa facilitation and cooperation on readmission. On the other hand, one may conclude that, since the revised CCV includes an integrated mechanism on cooperation on readmission, visa facilitation agreements can be replaced by the measures included in the Council's implementing decision, such as a reduction in the visa fee or in the time to decide on visa applications, or an increase in the period of validity of multiple entry visas. This would progressively reduce the spectrum of possibilities to offer visa liberalization regimes and, accordingly, inhibit the flexibility of the EU visa policy.

Another connected question that arises is whether readmission will constitute a distinct feature of the future EU visa policy with the aim of putting third countries under pressure to take responsibility for mobility originating from their territory. ${ }^{118}$ Admittedly, the EU readmission policy, far from ensuing from a specific legislative instrument, constitutes a more structural element of a wide range of external policies, such as trade and development aid. ${ }^{119}$ This is a crucial point, because one of the main concerns is about the effectiveness of the cooperation on readmission, which could be more relevant if linked with incentives stemming from agreements negotiated in different policy areas instead of limiting this to the visa policy. While such a scenario may be desirable and supported by a widespread practice of readmission clauses included in several agreements with third countries, a more cautious approach is necessary. When such readmission clauses are coupled with sanctions that restrict the potential benefits of specific policy instruments such as agreements on trade or development aid, for instance, the impact of these sanctions can cause more damages than a simple deprivation from visa facilitations.

Sub-Saharan countries, from which there is a large flow of irregular migration, are believed to be unsuitable to offer visa facilitation agreements as their cooperation on readmission is very limited. In this connection, instead of using the visa policy tools, the European Commission can implement several other political instruments, such as bilateral and regional policy dialogues and action plans, or consider any operational support and capacity building as well as a set of strategies that can stem the flows of irregular migrants. One option

118 See Vavoula (n 45).

119 T. Strik (2019). Migration deals and responsibility sharing: can the two go together?, in: S. Carrera, J. Santos Vara and T. Strik, Constitutionalising the External Dimensions of EU Migration Policies in Times of Crisis: Legality, Rule of Law and Fundamental Rights Reconsidered, Cheltenham: Edward Elgar, 57-74. 
has been included in the strategy set out in the 2020 Pact on Migration and Asylum aiming at launching Talent Partnerships to support legal migration and mobility with key partners, including African countries. ${ }^{120}$

\section{5}

\section{Concluding Remarks}

The EU visa policy plays a crucial role in developing a principled GAMM as it links the cooperation with third countries with the possibility to regulate access to the Schengen territory through the visa policy. Nonetheless, the revision of the CCV with its punitive shift relegates the EU visa policy to a mere migration management tool rather than upholding this policy as an effective instrument to design constructive cooperation with third countries.

The new punitive mechanism embedded in Article 25a of the revised CCV, threatening countries with visa sanctions, can raise controversial issues that will affect the pattern of cooperation between the EU and third countries in general. ${ }^{121}$ If, one the one hand, the European Commission has the mandate to permanently monitor third countries' cooperation on readmission, on the other hand, the question is whether this constitutes a major step forward in terms of effective border management. As highlighted in the previous sections, this new mechanism exacerbates the selectivity effects of the visa policy by discriminating between individual cases owing to the political performance of the country of nationality. Third country nationals are arbitrarily punished for a governmental conduct which is completely beyond their control. Ultimately, the practical effectiveness of this new punitive shift is questionable, considering that the top nationalities of people subjected to return decisions are nationals of countries whose nationals are exempt from visa obligation, and, accordingly, the mechanism under Article 25a would be irrelevant.

In conclusion, as emphasized by scholars, the reform of the Visa Code marks another step in the 'less for less' approach to the GAMM, ${ }^{122}$ insisting on applying negative incentives to third-country cooperation. Admittedly, readmission is a key policy of the EU and efforts to strengthen cooperation with third countries in this area are necessary. However, this cannot be detrimental to the effectiveness of other policies' objectives nor can this result in mechanisms encroaching upon fundamental legal principles, such as the prohibition

\footnotetext{
$120 \operatorname{COM}(2020) 609,22-23$.

121 Vavoula (n 45).

122 Strik (n 2), 322.
} 
of discrimination. A more principled approach to readmission requires more than mere punitive mechanisms. Instead, taking into consideration that in many cases the lack of cooperation on readmission ensues from the lack of resources or administrative capacity in a third country, more political and possibly economic investments in capacity building or development aid in third countries can determine in the long term more effective and fairer cooperation and a more constructive migration management. 